6. Wang H., Zhang J., Yu H. Elemental selenium at nano size possesses lower toxicity without compromising the fundamental effect on selenoenzymes: comparison with selenomethionine in mice // Free Radic. Biol. Med., 2007, V.42, N.10, P.1524-1533.

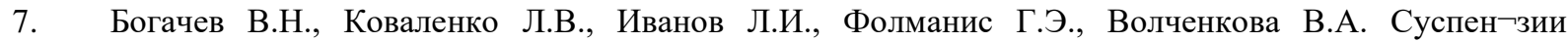
наноразмерного селена в растениеводстве.// Перспективные материалы, 2008, № 2, с 54-56.

8. Голубкина Н.А., Фолманис Г.Э., Тананаев И.Г. Сравнительная оценка аккумулирования наночастиц элементарного селена, селената и селенита натрия растениями рода Allium при внекорневом внесении элемента. // ДАН, 2012, том 444, № 2, с. 230-233.

9. Свирежев Ю.М. Кибернетика и урожай. В сб. «Кибернетика живого. Биология и информация», М.: Наука, 1984, с. 54-64.

\title{
Хорин В.В. \\ Воспитание детей и молодежи как фактор стабильного развития современного государства
}

doi: $10.18411 / s r-05-12-2021-34$

ГБОУ средняя школа № 305 (Россия, Санкт-Петербург)

Одним из факторов устойчивого и стабильного государства являются традиционные ценности: семья, школа, институт, социум. Существование общества совершенно невозможно без самой первой социальной группы - семьи, где закладывается «фундамент понятий и жизненных ценностей» [1]. Еще предки говорили: «Держава крепка, если семьи крепки!». Ведь именно в семье ребенок получает первые навыки общения с другими людьми и основными культурными ценностями. Изучение истории страны через судьбы людей, осознание ценности памятников культуры и искусства, воспитания любви к родному городу, стране [2].

Преемственность поколений и сохранение традиций, то, за что отвечает семья, являясь социальным институтом с определенным социальным положением и статусом каждого члена семьи, несет ответственность перед государством за воспитание будущего гражданина, способного укреплять мощь страны своими открытиями или работой на благо общества. История семьи, малой Родины, все это ведет к государству «великому и единому», как отметил Путин В.В., выступая перед школьниками в Тюмени в сентябре 2021 года: «Очень важно заниматься воспитанием детей и молодежи, но те, кто поучают, должны подходить с уважением к истории и правдивости событий, не искажая факты» [3].

Очень важным для воспитания детей и молодежи, как подрастающих граждан своей страны, является сочетание прямого обучения: современные способы подачи излагаемого материала и знание истории. Как показало время, самой стабильной и адекватной формой человеческого общежития, важнейшим институтом современного общества и его политической организации, является государство.

В нынешней геополитической обстановке, необходимо ли нам государство со стабильной экономикой?

Заглянем в учебник истории: а что такое государство?

Государство - это особая организация политической власти, которая располагает специальным аппаратом (механизмом) управления обществом для обеспечения его нормальной деятельности [4].

Государство существует для поддержания в обществе порядка, обеспечения и защиты интересов всех членов общества. Необходимость решения общих дел и проблем ставит перед государством определенные задачи, набор которых различен на разных стадиях развития общества. Познание значения государства, его роль в жизни общества, выражается в его функциях. Еще до школы и уроков истории неосознанно, но приходит понимание того, в каком государстве ты живешь, на каком языке говоришь? Кто твои родители, что является твоей Родиной? Все это начинается с семьи, заинтересованных 
родителей, и дальше от педагогов: первого учителя и коллектива в школе, где дети проводят большую часть своего времени. Именно поэтому роль специалистов в сфере образования огромна: именно они являются движущей силой, которая способствует обучению, воспитанию и подготовке молодых специалистов в различных областях. Увлеченных и заинтересованных людей, которые благодаря инновационному развитию в различных областях и передовым технологиям продвигают передовые идеи, что способствует развитию государства и престижу страны. Ежегодные встречи Президента Российской Федерации с аудиторией школьников, студентов или молодых специалистов, которые уже определились с выбором профессии, невероятно важны и несут огромный воспитательный потенциал. Работающие молодые специалисты и новаторы будут продвигать свои идеи и укреплять стабильность производственных отраслей, а школьники смогут выбрать для себя тот путь, который в дальнейшем приведет к выбору профессии, престижу выбранной специальности и в дальнейшем удовлетворению от выполняемой работы, что в свою очередь является одним из факторов стабильности государства.

Быстро развивается промышленность, медицина, различные области жизни, образование также дало большой виток развития. Даже космос покорился не только специалистам аэрокосмических технологий, но и представителям искусства кинорежиссерам и актерам: 5 октября 2021 года 37-летняя актриса Юлия Пересильд и 38-летний режиссер Клим Шипенко отправились на Международную космическую станцию для съемок фильма «Вызов». Благодаря грамотной политике государства и большому количеству специалистов, была проделана эта работа, которая стала неотъемлемой и важной частью истории современной России. Поддержание интереса у детей и молодежи к новым проектам и научным открытиям позволяет расширять кругозор и ввести в новый мир технологий, где педагог, учитель, наставник является проводником. Он, который дает верное направление и вектор к дальнейшему развитию и поиску, благодаря своему опыту и накопленным знаниям. Успех образования напрямую зависит от личности педагога, его информированности, профессионального и творческого потенциала и возможностей, общекультурной подготовки, его желания самообразовываться и развиваться. Педагог является одним из субъектов образовательного процесса и он, как сильная и творческая личность - может «повести за собой», заинтересовать и увлечь учащихся идеей, процессом поиска инноваций и улучшения качества жизни, а значит к развитию стабильного современного государства.

$$
* * *
$$

1. Бурова С.Н, Социология брака и семьи: история, теоретические основы, персоналии/ С.Н. Бурова; Белорусский государственный университет. - Минск: Право и экономика, 2010. - 444 с. (Серия «Гуманитарные науки»)

2. Концепция воспитания юных петербуржцев: учебно-методическое пособие / Е.Н. Барышников, М.Р. Илакавичус, В.Н. Раскалинос и др.; под науч. ред. Е.Н. Шавриновой. - СПб.: СПб АППО, 2021.

3. Открытый урок. Встреча В.В. Путина со школьниками от 01.09.2021.

4. Певцова Е.А., Право: основы правовой культуры: учебник для 10 классов общеобразовательных учреждений. Базовый и углубленный уровни в 2 ч. Ч.1/. Е.А. Певцова - М.: ООО «Русское слово»учебник», 2017. - 3-12 с. - (Инновационная школа). 